\title{
BUSINESS MODEL RENEWAL IN CONTEXT OF INTEGRATED SOLUTIONS DELIVERY: A NETWORK PERSPECTIVE
}

\author{
Karoliina RAJAKALLIO a,*, Miro RISTIMÄKI a , Mia ANDELIN a, Seppo JUNNILA a \\ a Department of Real Estate, Planning and Geoinformatics, School of Engineering, Aalto University, \\ P.O. Box 15800, 00076 Aalto, Finland
}

Received 29 January 2015; accepted 15 April 2016

\begin{abstract}
Successful business model renewal requires the companies to understand the changes that the new business model causes with respect to their activities, value drivers and value appropriation logic. The study employs a comparative case study strategy. Conceptualizing business models as activities, the changes that adopting an integrated solution business model to implement a real estate development causes to the business models of companies in the project delivery network, compared to their business models applied in conventional project delivery networks following a disintegrated approach, is analyzed. The findings suggest that the shift towards more integrated project delivery models causes significant changes in the alignment of value drivers and value appropriation mechanisms across the network of firms. Simultaneously, companies adhere to their existing activity content and governance. The results contradict previous studies on the organizational impact of shift towards integrated solutions. Existing research on integrated solutions and alliances has primarily focused on developing practices from the perspective of a customer - producer relationship. This study gives valuable insights related the importance of the internal logic of the service providers in achieving successful project coalition.
\end{abstract}

KEYWORDS: Business model; Integrated solutions; Risk; Activities; Value

SUPPLEMENTARY MATERIAL associated with this article can be found, in the online version, at doi:10.3846/1648715X.2016.1249533

\section{INTRODUCTION}

The complexity related to buildings and construction processes has increased significantly in the recent decade. Focus on life-cycle performance of buildings, new technological solutions, increasing demand of customers for total solutions, and the increased environmental dynamics and uncertainty all challenge the traditional business models in the real estate and construction (REC) sector.

For organizations, one way to manage complexity is the increased integration of value chains. For real estate and construction sector companies this has meant adopting new business models that are based on product and service deliveries in order to provide one integrated solution to the client (Bresnen, Marshall 2000a; Dainty et al. 2001; Leiringer, Bröchner 2010). However, several challenges have been identified, that affect the adoption of new

\footnotetext{
* Corresponding author. E-mail: karoliina.rajakallio@aalto.fi
}

business models in the real estate and construction sector firms: inability to manage change in the working practices (Brady et al. 2005a; Brewer et al. 2013; Leiringer, Schweber 2010); slow transfer of new practices across projects (Dubois, Gadde 2002a; Nam, Tatum 1988); the varying competence of clients (Barlow 2000; Blayse, Manley 2004) and unoptimized incentive structures. Also the established internal routines and cultures of firms may affect the adoption of new business models, (Brady et al. 2005a; Leiringer, Schweber 2010).

Existing studies on construction industry business models, including integrated solutions, have employed, implicitly or explicitly, the perspective of a single firm. We suggest that by examining the inter-firm related interactions we obtain a more comprehensive understanding how REC sector firms may develop and manage the shift towards integrated business models more efficiently. 
Despite the fact that the REC sector is highly fragmented and necessitate a high amount of inter-organizational collaboration (e.g. Nam, Tatum 1988), existing studies on construction industry business models, including integrated solutions, have employed, implicitly or explicitly, the perspective of a single firm. There is a dearth of studies that examine the influences of integrated business models on the relationships between firms. By examining the inter-firm related interactions we obtain a more comprehensive understanding how REC sector firms may develop and manage the shift towards integrated business models more efficiently.

The purpose of this paper is to analyze the changes that adopting an integrated solution business model to implement a real estate development causes to the business models of companies in the project delivery network, compared to their business models applied in conventional project delivery networks following a disintegrated approach. The issue here is not immediately about project performance, rather, it is about the performance of firms whose business is to engage with others in delivering projects.

Business model is a construct for identifying the strategic, organizational and economic drivers of the participants to engage in to business transactions within the value system. (Zott, Amit 2008). The paper adopts an analytical lens of the business model as an activity system, as suggested by Amit and Zott in one of their seminal papers (Zott, Amit 2010). It enables the analysis of the entire value creating system of a focal firm, without being bound to the organizational or transactional boundaries, as set forth by contractual theories (Sheehan, Foss 2007; Zott, Amit 2008). In the context of the real estate and construction sector, this approach is also suggested by Leiringer and Bröchner (2010), who state that understanding firms' business model choices requires looking into the "black box" of firm activities at intra- and interfirm levels (Leiringer, Bröchner 2010).

The paper has five sections. Section 2 presents the theoretical framework used in the study. As the area of business models in REC sector is relatively new, we first build a theoretical framework that synthesizes the different business model elements mentioned in extant literature, building on Zott and Amit (2010) conceptual work. Section 3 summarizes the case study method and research approach. Then the analysis based on an in-depth investigation and comparison of the cases is presented. The paper concludes with key findings of the study and their implications for future research and practice.

\section{LITERATURE REVIEW}

Before presenting the theoretical framework applied in the study, we first review the central literature on business models in general management literature and reflect it with related literature in the real estate and construction context. There is lack of publications that apply the business model construct directly in the REC sector. Therefore, we identify the key aspects affecting the choice of business models in REC sector by summarizing the findings from studies parallel to business models from integration, supply chain and network perspectives.

\subsection{The business model construct}

Business models emphasize a firm-centric yet boundary-spanning, holistic approach toward explaining how companies do business, and fill a conceptual gap between business strategy and operational business planning (Zott et al. 2011). There are multiple definitions of a business model (c.f. Chesbrough, Rosenbloom 2002; Osterwalder et al. 2005; Teece 2010; Zott et al. 2011). We follow here the definition by Teece (2010), who states that "a business model articulates the logic and provides data and other evidence that demonstrates how a business creates and delivers value to customers. It also outlines the architecture of revenues, costs, and profits associated with the business enterprise delivering that value".

The concept of the business model applies not only at a focal firm level, but also includes the network of the focal firm that is part of its value proposition, such as partners and sub-suppliers. As a consequence, the business models of networked firms may be overlapping or complementary (Mason, Spring 2011). The real estate and construction sector is highly networked and characterized by interdependence of its actors (Nam, Tatum 1988), making a business model a particularly suitable construct for analyzing the strategic, organizational and economic drivers of participants in the sectors' value systems (Zott, Amit 2008).

\subsection{Factors affecting business models in real estate and construction}

The vast majority of business model literature and related analytical constructs have been developed from the basis of consumer industry and IT sector. Therefore when applying business model concepts in a capital goods industry, such as real estate and construction, the differences compared 
to consumer market should be noted (Brady et al. 2005a; Davies 2004; Gann, Salter 2000).

Due to the project-based nature of the sector (Davies 2004; Hobday 1998), adoption of innovations such as new business models is challenging, because new activity links, resource ties, and actor bonds created in projects are considered projectspecific and temporary and thus not transferred to the firm level and incorporated to the firm's processes (Bygballe, Ingemansson 2014). Conversely, new ways of organizing projects is difficult, if they are not supported or aligned with the business processes or resources at the firm level (Gann, Salter 2000). For example Consoli (2006) identified differing views on control and power issues in the contractor - operator relationship hampering implementation of integrated solutions. Also, FM service provider's lack of knowledge on design issues and capacity may be a barrier to implementing integration successfully (Brewer et al. 2013; Jensen 2009).

Other key differences may be identified by examining the value stream of the products. Davies (2004) has identified four main value stream stages in a typical capital goods industry: the manufacture of components; the design and integration of components into a functioning system, i.e. "systems integration" services; the operation and maintenance of a system during its life span i.e. "operational services"; and the provision of services to the final consumer. It also recognizes the key role of systems integration in the delivery of integrated solutions to coordinate the various inputs of collaborating organizations (Gann, Salter 2000; Rutten et al. 2009; Winch 2001). Each of these stages in the value stream is progressively closer to the final consumer, such as the building tenant or customer. The value chains in the REC sector are however not as linear as depicted by Davies (2004). In practice, each solution must be negotiated with a multitude of actors in the network (Winch 1998) and with a mix of expert-based and formal influences (Liu et al. 2003).

Means to deepen inter-organizational collaboration in construction that have been discovered or suggested include the quasifirm (Eccles 1981), partnering and alliancing (Anvuur, Kumaraswamy 2007; Bresnen, Marshall 2000b), long-term business relationships (Nam, Tatum 1992), and integrated solutions (Brady et al. 2005b). Studies examining the integration in real estate and construction sector business models often focus on formal contractual and technical arrangements. However, the importance of non-transactional aspects of integration, is also acknowledged. Nam and Tatum (1992) identified owner's leadership, the long-term relationship, employing integration champions and the professionalism of project participants as non-contractual means of integration on construction projects. In addition, the creation of collective identity such as unrestricted knowledge sharing, a no-blame culture, shared direction and goals, equality and fairness, and trust for a project organization culture that is conducive to performance, is increasingly acknowledged (Ankrah et al. 2009; Baiden et al. 2006).

The clients' role in real estate and construction sector is central but often ambiguous. The client is central in determining the shared direction and the goals and of the project network (Briscoe et al. 2004). But end users, e.g. residents and commercial tenants, and clients, e.g. investors, may have differing expectations. Real estate and construction is characterized as operating in a double-sided market, which affects the business horizon of the actors, and their perception about customer relations. The actual users of the buildings are often tenants that appraise the quality of the real estate through its ability to support their core business, and provide cash flow through rental and service fees. However, the buildings are also investment assets that are purchased and sold in the investment markets, where value is appraised though the building's ability to attract and retain rental income and the investor's ability to increase asset value, e.g. though market and financial risk reduction (Goddard, Marcum 2012). Agreement among the participants over whose demands and expectations are prioritized is therefore important for the integration of the network (Lindahl, Ryd 2007; Majamaa et al. 2008). Also, when analyzing the value created though real estate development projects the different aspects of customers, and their impact on the choice of activities and dominant drivers of value appropriation should be noted.

Summarizing, REC sector business models are best understood through looking both at the project level and firm level business models (Wikström et al. 2010). Project level business models are best understood by analyzing the network of companies and the mutual alignment of the business models of the participating companies. A change in the project delivery mode changes the way companies' business models are constructed and also how these are linked together. This in turn, is mediated by the business processes, which are applied at firm level and in permanent networks, shared goals and perception of the client. 


\subsection{Theoretical framework: business models as activity systems}

In this paper, we analyze the cases utilizing Zott and Amit (2010) conceptualization of business models as activity systems. An activity in a focal firm's business model can be viewed as the engagement of human, physical or capital resources of any party to the business model (the focal firm, end customers, vendors, etc.) to serve a specific purpose toward the fulfillment of the overall objective (Zott, Amit 2010). Their framework of activity-based business model framework consists of 1) design elements - content, structure and governance of activities - that describe the architecture of an activity system; and 2) design themes - novelty, lock-in, complementarities and efficiency - that describe the sources of the activity system's value creation. Next, we describe in more detail the content of these constructs and their relation to the established theories in strategic management literature.

\section{Design elements}

Activities, routines, and business processes are the mechanisms through which resources and capabilities get exposed to market processes where their ultimate value and ability to generate competitive advantage are realized (c.f. Porter 1985, 1991; Stabell, Fjelstad 1998). Business models extends the boundaries of the focal firm so that the firm activities may transcend the focal firm and span its boundaries (Zott, Amit 2010). The architecture of the firm's activity system, captures how the focal firm is embedded in its "ecology", i.e., in its multiple networks of current and potential suppliers, partners and customers (Zott, Amit 2010; Thomas et al. 2014). The design elements of an activity system are content, structure and governance:

- Activity system content refers to the selection of activities, i.e. those that are performed.

- Activity system structure describes how the activities are linked (e.g., the sequencing between them), and it also captures their importance for the business model, for example, in terms of their core, supporting or peripheral nature.

- Activity system governance refers to who performs the activities. Subcontracting, for example, represents one possible approach to activity system governance.

\section{Design themes}

An activity system can also be characterized through design themes, which describe the degree to which the business model design elements (i.e. activities) are orchestrated and connected by distinct value drivers (Zott, Amit 2010). Activity drivers are generic, structural factors that are more or less under management control, which impact the cost incurred or value delivered by an activity (Porter 1985); they explain why a firm's activity set generates more cost or value than its rivals. Drivers may counter-act each other within the same activity or may have different impacts across different activities (Porter 1985). Therefore the benefit of an individual driver on an activity needs to be balanced with other drivers that also affect the activity, between other activities of the firm, and in relation to the competitor's activities.

In their empirical studies, Amit and Zott (2001) found out that the common design themes that characterize and connect the elements of activity systems are: Novelty, lock-In, Complementarities and Efficiency (summarized by the acronym NICE). In practice, a business model may be orchestrated by any design theme or their combination, such that the presence of each value driver can enhance the effectiveness of any other driver.

- Novelty: The essence of novelty-centered activity system design is the adoption of new activities (content), and/or new ways of linking the activities (structure), and/or new ways of governing the activities (governance).

- Efficiency: Efficiency-centered design refers to how firms use their activity system design to aim at achieving greater efficiency through reducing transaction costs, or achieving efficiency through their activity system content and structure.

- Complementarities: Complementarities are present whenever bundling activities within a system provides more value than running activities separately. Hence, complementarities can be expected to increase value by enabling revenue increases.

- Lock-in: Activity systems can also be designed for lock-in, their power to keep third parties attracted as business model participants. Lock-in can be manifested as switching costs, or as network externalities that derive from the structure, content and/or governance of the activity system. Lock-in prevents the migration of customers and strategic partners to competitors, thus creating barriers to entry that enhance the value capturing potential of the activity system e.g. through innovations. 


\section{METHODS}

\subsection{Case study design}

Two case studies were conducted to examine what impacts a change in the procurement context of a real estate development project has to the business models of companies participating to the project delivery. In this study, differences between business models in a context of a traditional, disintegrated project delivery model and an integrated project delivery model are examined. A comparative case study was selected as an appropriate research strategy of the study, as its purpose is to understand a change - the similarities and differences between the two case setting (Yin 2003). A case study is recommended when the boundaries between the phenomenon and context are unclear and the understanding the informal structures is important (Yin 2003). As the key factor in this study is to analyze the impact of contextual factors and as business models can only be analyzed in a context of the company's industry network, a case study approach is particularly appropriate.

To investigate the research question, we had an opportunity compare of two real estate development case settings that employed almost identical networks of firms, but applied two different logics of delivering the building life-cycle: 1 ) an integrated delivery model, and 2) a conventional disintegrated delivery model. The business models of companies in both case settings are analyzed with a similar scope, which consists of activities related to: project development (conceptual development, bid preparation); construction project implementation (design and construction) and the operation \& maintenance of the building (maintenance, repairs and replacements). Our unit of analysis is twofold: first the unit of analysis is the project level business models of the three key companies participating to the project delivery in each case setting. Secondly, the interplay of the company level business models is examined from a network perspective (cf. Wikström et al. 2010).

\subsection{Case selection and collection of data}

We considered several factors in selecting the cases. The cases were selected with the intention to find polar types of integrated and disintegrated project delivery modes in which the process of interest is transparently observable (Eisenhardt 1989; Pettigrew 1990; Yin, 2003). Secondly, we looked for case settings that involved similar organizations, enabling the analysis of matching actors, in differ- ent procurement contexts, to follow a replication logic (Eisenhardt 1989; Yin 2003). In addition, the business models of participating companies have been analyzed with an identical scope: throughout project initiation, construction and maintenance. Replication logic is useful, because cases are expected to yield similar information or findings, or findings that are contrary but predictable and as such allow us to build more robust inductive theories across multiple, heterogeneous cases (Eisenhardt 1989). This allows particular factors (e.g. organizations, managerial systems) to be, in essence, "held constant" while others (e.g. costs, activities) are left free to vary as they would naturally (Meredith 1998). A final and practical factor that affected our selection of cases was the possibility to gain rich data through participant observation. This enabled access to informal mechanisms of management, which was assessed as being valuable and substantially increasing the quality of data in addition to interviews and project documentation. That is, the triangulation made possible by multiple data collection methods provides stronger substantiation of conclusions and interpretation of the findings (Eisenhardt 1989).

Primary data consisted of the main contract of the projects, 15 semi-structured interviews of key personnel of the case companies, clients of the case projects and 7-12 months of participant observatory in both cases, conducted between 2013 and 2014. During this period, the authors participated in over 70 meetings and between the developer organization and the client, the financiers and private investors, the contractor and subcontractors, and FM service providers at technical and operational level. In addition, 18 site visits were made. Secondary sources utilized were presentations materials, project websites and other project material. A list of data sources, collected data and its use in the analysis is presented in the Appendix 1.

The data collection took place during the construction and maintenance phases of the projects to ensure that the value network under study was actively working on their business model and project delivery. During the observation period, the Integra project was in the construction phase with two of seven buildings having been completed and the Standard having completed the sale of the first office building to a real estate investment fund.

The interviewees were selected based on their involvement in the project contract design and bidding process and/or their have direct operational responsibility to implement the contract. A full list of interviewees is presented in the Supplementary 
material Table S1 of the paper. As the project organizations are small, the interviews covered all of the key personnel involved in to the direct management of the case project delivery network, and the client representatives. Each interview lasted approximately 1.5 hours. They were recorded, and later transcribed and coded using qualitative content analysis software Atlas.ti. The interview results and on-site observations were mirrored against contract documentation to verify the credibility of the themes found in the data analysis. Participant observations were used to interpret findings in the case context and to identify dynamics across the framework constructs, informal authority structures and conflict resolution mechanisms. In addition, initial findings and results of data interpretation was sent to the informants for verification.

\subsection{Data analysis}

Drawing from the relevant literature, as discussed in the previous chapter, a conceptual framework was built to guide data collection. However, the theoretical propositions were used as flexible guidelines rather that stringent limits. The purpose for this was to avoid constraining the research by imposing predetermined theoretical perspectives (Eisenhardt 1989). Emergent data were incorporated into the analysis applying systematic combining of the emerging issues and ongoing development of the interview templates (Dubois, Gadde 2002b; Eisenhardt 1989).

First, data from each company in both case settings were analyzed separately to form a complete picture of the business model elements of individual companies, activities and value drivers, at each stage of the project: bid preparation, design and construction, and operations. These business model elements were then reflected with business logic of the particular case setting to form an understanding of the business model elements at network level. During the analysis, new themes outside the original theoretical framework were found. In addition, the coding of data revealed several contextual factors affecting the choices made in the cases, such as trust and client relationship. As a consequence, the analytical framework was subsequently complemented and the revised framework was then applied to analyze both cases. Cross-case analysis was made through comparisons of the cases to determine where similarities and differences existed and to identify the drivers of the related business model choices (Yin 2003).

\subsection{Description of case settings}

The first case setting is an integrated project delivery model (later: Integra) and the second case setting is a project delivery model currently typical for the industry (later: Standard). The analyzed firms participating to the projects are the exact same companies in both settings: developer, contractor and FM service provider (later: Integra/ developer, Integra/contractor, Integra/FM service provider and Standard/developer, Standard/contractor, Standard/FM service provider). The key activities of firms and their sequencing of both case settings is depicted in the Figure 1.

The first case setting (Integra) is a hospital facility, in Stockholm, Sweden. The activities throughout of the buildings' life cycle are arranged applying an integrated solutions approach. The construction, service and life-cycle costs of the buildings are recovered during the concession duration through client's monthly fees, against fulfilled functional requirements over 30 years. In addition, the concession provides funding for $50 \%$ of the initial investment costs through private financiers.

The consortium firms agree to the terms of the joint consortium contracts that stipulate the mutual governance and division of costs and risks of the concession. After the project development phase, the Integra/developer founded a Special Purpose Vehicle (SPV) as limited liability company through which it manages the main concession contract with the client and integrates construction, maintenance and life-cycle services provision. The SPV rolls down the main contract in a form of a subcontract to the Integra/Contractor, along with the risk of construction costs and schedule; and to Integra/FM service provider, with the risk of the technical performance of the buildings and related maintenance costs. The risk for life-cycle costs of the buildings, i.e. costs of investments needed to maintain the technical residual value of the buildings at the agreed level remain the responsibility of the SPVs.

The second case setting, Standard, is a commercial facility development in Helsinki, Finland. The activities of its value stream are arranged following a "standard industry logic" as depicted in the Figure 1. The Standard/developer initiates the project by defining the building's business concept and initial design. The Standard/developer makes a contract with Standard/contractor that also shares the same mother company as the Stand$\operatorname{ard} /$ developer, for the construction services. Once 


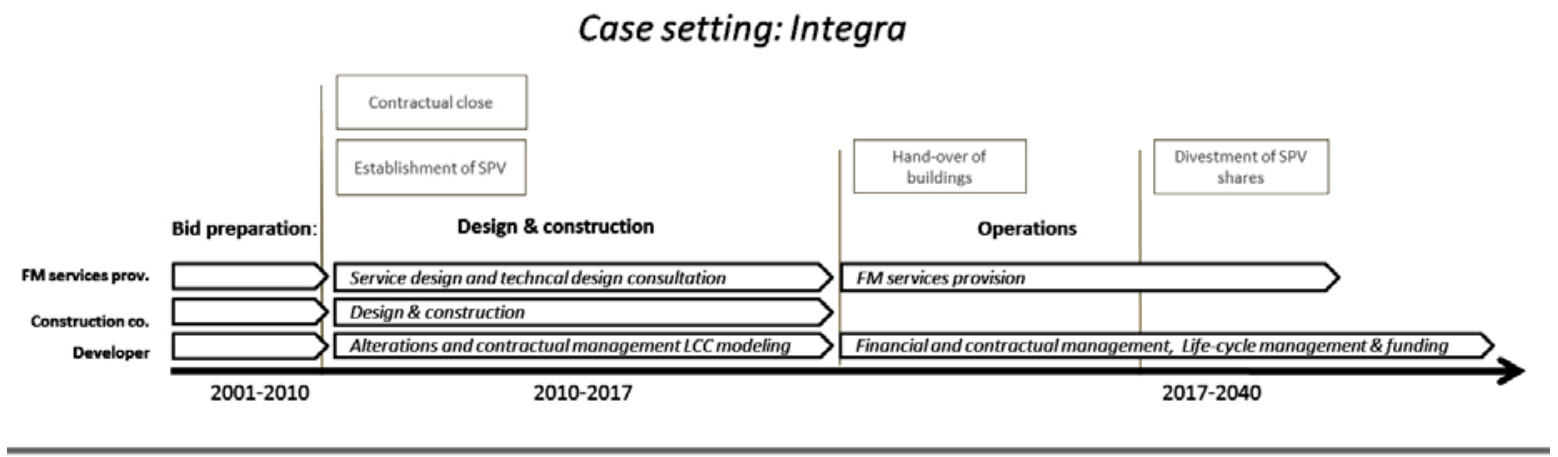

\section{Case setting: Standard}

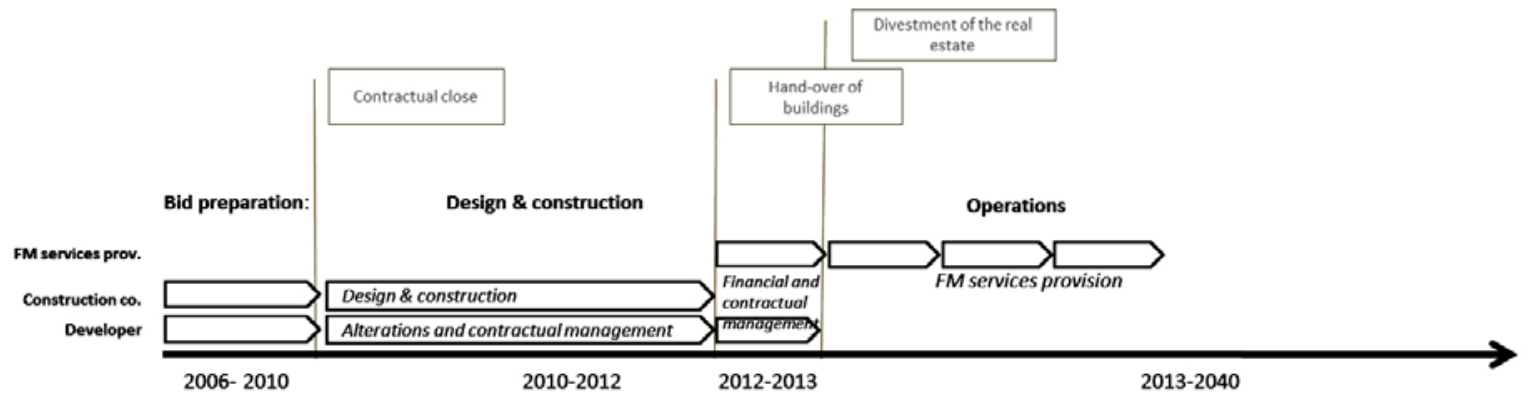

Fig. 1. Key activities of Integra and Standard case settings

the building has been completed, it also makes a contract for the provision of the operational and maintenance services with Standard/FM service provider. The Standard/developer also leases the facilities to the market and finally divests the building to an external investor after completion of the construction. At this point, also the FM service contract is transferred to the new owner.

\section{RESULTS: CROSS-CASE ANALYSIS}

In this chapter, we show the results of a crosscase analysis, to explore the changes that adopting an integrated solution business model at project level causes to the business models of companies in the project delivery network, compared to their business models applied in conventional project delivery networks. The applied Zott and Amit (2010) analytical framework is described in the theoretical section of this paper. Detailed results from the within case analysis can be found in the Tables S2 and S3 in the Supplementary material of this paper, where the business model design elements (i.e. activity content, structure and governance) model is mapped against the design themes (i.e. value drivers) separately for each company in both case settings. The cross-case comparison is conducted separately for each "pair" of companies, e.g. Integra contractor vs. Standard contractor, and summarized a network level.
The findings of cross-case analysis of design themes are summarized in Table 1. The first items presented are the project delivery phases when the identified value driver is dominant. Secondly, the text in italic describes the value appropriation mechanism of the identified value drivers.

\subsection{Business model design elements}

The companies involved in both of the cases have arranged the delivery of a building life cycle utilizing similar division of resources. Also the governance of activities follows a similar pattern in both case settings, i.e. each of the main activities of the project delivery are run by separated commercial units (governance). However, due to different principal means of value appropriation, we find differences in in activities related to life cycle modelling and codification (content) and the scheduling and duration (structure) of the activities across the firms in different case settings.

Compared to the Standard case setting, the Integra/Developer and Integra/FM Service Provider have additional activities of codification of the life-cycle data and life-cycle management in their business model. The activities of the companies in the Integra case setting are also more overlapping than in the Standard cases setting. The Integra/ Developer remains as a shareholder of the buildings and continues to manage their life-cycle funds throughout the concession, until life-cycle risks 
have been lowered sufficiently to enable divestment of shares of the SPV. Integra/FM service provider in turn is active in defining its services and their commercial model already at bid preparation phase. In contrast, in the Standard case, the FM Service Provider's activities start once the building is being completed, its activities being efficiently adapted to the technical solutions implemented in the building.

In Integra, additional activities are needed to ensure that the project delivery fulfills the set technical quality and service performance requirements while not exceeding the acceptable costs levels and utilizing premises for long-term value creation and subsequent appropriation. In practice, these activities include a multitude of informal relationship management activities and unofficial negotiations between the network parties and the client, in order to resolve issues through bargaining (Brewer et al. 2013). It is notable that these activities are not conducted only by the Integra/ Developer acting as the system integrator (Brady et al. 2005b; Winch 2001), but also by the Integra/ contractor and Integra/FM service provider.

\subsection{Business model design themes}

We see that in the Integra case setting, the activities of concession parties, Developer, Contractor and FM Service Provider, are moderated through the shared design themes. The relative impact of each theme, however, varies depending on the phase of the building value stream: During the project development phase, the focus is on novelty. The role of efficiency becomes dominant after the contractual close, at which point the concession had taken over the risks related to the investment and operational costs. Lock-in and complementarities are especially present in the business model of Integra/Developer and Integra/FM Service provider. Striving for efficiency is enhanced though lock-in that enables the Integra/Developer's and the Integra/FM Service Provider's value capture throughout the life-cycle of the building.

In the Standard case setting, we see that the identified value drivers of the companies are less complementary than in the Integra case setting. During the project development, Standard/Developer focuses on innovations. After contractual close, the focus is on efficiency for all parties. However, the efficiency is determined through short term cost savings, as there is no lock-in to balance between investment and operational costs. Lock-in is not identified as an effective business model design theme, as the completed building is immediately sold to an investor based on market terms and the value appropriation of the Standard/Developer or FM service provider are not dependent on the operational performance of the building.

In both cases, the Contractor is responsible for executing the building construction following a design \& build contract, i.e. they carry the risks related to building design and construction in time and with fixed budget. In both case settings, the dominant value driver for contractor organisations is efficiency, Innovations were also supporting efficiency as the primary design theme of the contractors' business model, such as the Standard/Contractor's utilisation of pre-fabricated HVAC channelling. Neither of the contracting organisations did have lock-in is as a visible design theme, as their activities do not stretch beyond the design \& construction phase of the buildings.

The activity system of the Integra case at the network level (i.e. the level of project delivery) is dominated by high complementariness of the business models of the firms, that visible in the activity system structure and value drivers: For example, the Integra/Developer was dependent on the activities and financial capabilities of the Integra/Contractor and the Integra/FM Service Provider in design and delivery the building and its operations. In addition, the feasibility of FM service provision is leveraged through technical solutions provided by the Integra/Contractor. Its design process is in turn mediated through Integra/Developer's capabilities. Lock-in enables utilization of the learning curve and knowledge transfer. Without the lock-in provided by the long term concession, uncertainties related to client requirements and time could not be offset by learning and investment on process development.

The sources of the disintegrated value drivers in the Standard case may be traced back to the divergent perception of who was the primary client by the developer, contractor and FM service provider. The primary client of Standard/developer were future investors, the primary client for the Standard/FM service provider were users and for the Standard/Contractor it was the Standard/Developer. This approach resulted in the organization of the network's activities in a linear fashion with limited complementarity. In contrast, in the Integra case setting there was a more shared understanding of the user as the primary client of the consortium. 


\subsection{Additional value drivers-risk}

In addition to the business model design themes identified by Zott and Amit (2010), the analysis of the two cases settings identifies risk as a fifth design theme and probably a dominant value driver. Risk was identified to impact the cost incurred or value delivered by an activity in three main ways: 1) The management of risk was identified to create a significant part of the client's value proposition in both cases; 2) The high risk taking of companies was seen to strengthen the effect of other design themes, through promoting operational efficiency and in some cases innovations; and 3) The management of risk and subsequent deflation of the perceived risk level of the project deliveries resulted in asset appreciation and thus created value for the developers.

In the Integra case, by taking over the risks associated with the cost and time overruns of the construction, service provision and technical lifecycle, i.e. technical and operational risks of the project, the consortium provided the client the "ability to implement" the investment in the first place. The implementation of the hospital in one phase was seen to have been impossible due to the client's lack of internal resources and capabilities, and risk propensity. In the Standard case, the minimization of the market risk related to the real estate increased the attractiveness of the buildings as an investment.

\section{Developer}

By managing the operational and technical risks of the construction, the Integra/Developer is expected to lower the overall risk exposure of the concession, enabling a favourable re-financing once the construction has been completed. Once the operations and related costs of the hospital have been stabilised, the Developer expects the shares of the SPV to be sold with profit.

In the Standard case, the Standard/developer carries the major market risk of the project delivery related to the rental levels and yield levels. Its activities are designed to minimize the accumulation of additional risks, by favoring contracts that transfer the technical, operational and life-cycle risks to its subcontractors. Risk's role in customer value creation is emphasized through minimization of the market risk of the asset. As a consequence, similar to the case in Integra, the reduction of the investment risk level results in asset appreciation.

\section{Contractor}

In both cases, the Contractor is responsible for executing the building construction following a de- sign \& build contract, i.e. they carry the risks related to building design and construction in time and with fixed budget. In turn, the high investment and operational risk position provided Integra/Contractor and Standard/Contractor a strong basis for a better than average project margin, as a results of the contractor having superior operational and technical risk management capabilities compared to its client.

The prominent role of risk in project value creation promotes activity system content that minimises technical risk of the building and support the functional requirements that must be met. However, the high risk position could also be seen to impede value creation through discouraging product or technology innovations and making the operations and project delivery more inflexible, once the product and service specifications have been agreed in the contractual close. In addition, it incentivizes incremental innovations aimed at minimising operational risk or promoting efficiency.

\section{FM Service provider}

The level of absorbed operational risk and customer lock-in is very different between the Integra and the Standard cases. The Integra/FM Service Provider, as part of the consortium, has committed to providing property maintenance services to its client against a fixed fee and functional criteria. As such it carries the risk of operational performance of the maintenance works and technical risks related to the maintenance and repair needs of the building parts. As a consequence, the Integra /FM Service Provider has, compared to the Standard case, added activities related to maintenance design and consultation of material and component choices into its activity system.

In turn, the high investment and operational risk position provided the Integra/FM Service Provider the possibility to gain higher than average margins given that it was able to excel in operational efficiency and to manage technical and operational risks during the operational phase of the buildings. This is enabled by a strong customer lock-in. This encourages activities that promote operational innovations and fully utilizes the acquired knowledge on customer needs. In the Standard case, the FM service contract period is "until further notice", with a notice of six months. In practice, this forces the Standard/FM service provider to implement standard operational processes with limited adaptation to customer needs or opportunities for operational innovations. 
Table 1. Comparison of value drivers and value appropriation mechanisms of the cases

\begin{tabular}{|c|c|c|c|c|c|c|}
\hline & \multicolumn{2}{|l|}{ Developer } & \multicolumn{2}{|l|}{ Contractor } & \multicolumn{2}{|l|}{ FM service provider } \\
\hline & Integra & Standard & Integra & Standard & Integra & Standard \\
\hline Novelty & $\begin{array}{l}\text { * Project develop- } \\
\text { ment } \\
\text { Creating business } \\
\text { opportunities, i.e. } \\
\text { winning the con- } \\
\text { tract } \\
\text { Creating value for } \\
\text { the client (user) } \\
\text { (e.g. improved } \\
\text { logistics, environ- } \\
\text { mental perfor- } \\
\text { mance) }\end{array}$ & $\begin{array}{l}\text { * Project develop- } \\
\text { ment } \\
\text { Creating value for } \\
\text { the client (tenants } \\
\text { and investors) }\end{array}$ & $\begin{array}{l}\text { ** Project devel- } \\
\text { opment } \\
\text { Creating business } \\
\text { opportunities } \\
\text { (winning the con- } \\
\text { tract) } \\
\text { Creating value for } \\
\text { the client (user), } \\
\text { e.g. improved } \\
\text { logistics, environ- } \\
\text { mental perfor- } \\
\text { mance } \\
\text { Maintaining } \\
\text { margin of the de- } \\
\text { sign \& construc- } \\
\text { tion, e.g. through } \\
\text { optimising build- } \\
\text { ability of solutions }\end{array}$ & $\begin{array}{l}\text { * Design \& con- } \\
\text { struction } \\
\text { Creating value for } \\
\text { the client (devel- } \\
\text { oper) } \\
\text { Maintaining } \\
\text { margin of the de- } \\
\text { sign \& construc- } \\
\text { tion, e.g. through } \\
\text { optimising build- } \\
\text { ability of solutions }\end{array}$ & $\begin{array}{l}\text { * Project develop- } \\
\text { ment } \\
\text { Creating business } \\
\text { opportunities (win- } \\
\text { ning the contract) } \\
\text { Creating value for } \\
\text { the client (user), } \\
\text { e.g. improved } \\
\text { logistics, environ- } \\
\text { mental perfor- } \\
\text { mance } \\
\text { Maintaining } \\
\text { margin of the } \\
\text { FM services, e.g. } \\
\text { through incremen- } \\
\text { tal innovations in } \\
\text { operations }\end{array}$ & Not identified \\
\hline Efficiency & $\begin{array}{l}\text { * Design \& con- } \\
\text { struction, opera- } \\
\text { tions } \\
\text { Creating value for } \\
\text { the client (user) } \\
\text { Maintaining the } \\
\text { margin of the life- } \\
\text { cycle management } \\
\text { operations }\end{array}$ & $\begin{array}{l}{ }^{*} \text { Design \& con- } \\
\text { struction } \\
\text { Maintaining the } \\
\text { margin of the } \\
\text { investment, not } \\
\text { exceeding bound- } \\
\text { ary conditions of } \\
\text { investment costs } \\
\text { and market rental } \\
\text { rates }\end{array}$ & $\begin{array}{l}\text { * Design \& con- } \\
\text { struction } \\
\text { Maintaining } \\
\text { margin of the de- } \\
\text { sign \& construc- } \\
\text { tion works }\end{array}$ & $\begin{array}{l}\text { * Design \& con- } \\
\text { struction } \\
\text { Maintaining } \\
\text { margin of the de- } \\
\text { sign \& construc- } \\
\text { tion works }\end{array}$ & $\begin{array}{l}* \text { Design \& con- } \\
\text { struction, opera- } \\
\text { tions } \\
\text { Maintaining } \\
\text { margin of the FM } \\
\text { services }\end{array}$ & $\begin{array}{l}\text { * Operations } \\
\text { Maintaining } \\
\text { the margin of } \\
\text { the service }\end{array}$ \\
\hline $\begin{array}{l}\text { Comple- } \\
\text { mentari- } \\
\text { ties }\end{array}$ & $\begin{array}{l}{ }^{*} \text { Project develop- } \\
\text { ment, design \& } \\
\text { construction, op- } \\
\text { erations } \\
\text { Maintaining the } \\
\text { margin of the life- } \\
\text { cycle management } \\
\text { operations } \\
\text { Creating value for } \\
\text { the client (user), } \\
\text { e.g. increased risk } \\
\text { absorption, focus } \\
\text { on core business }\end{array}$ & $\begin{array}{l}\text { * Project develop- } \\
\text { ment, Design \& } \\
\text { construction } \\
\text { Maintaining the } \\
\text { margin of the } \\
\text { investment, not } \\
\text { exceeding bound- } \\
\text { ary conditions of } \\
\text { investment costs } \\
\text { and market rental } \\
\text { rates } \\
\text { Creating value for } \\
\text { the client (tenants } \\
\text { and investors) }\end{array}$ & $\begin{array}{l}\text { Not identified at } \\
\text { network level } \\
\text { No immediate } \\
\text { value appropria- } \\
\text { tion from optimis- } \\
\text { ing life-cycle costs } \\
\text { and FM service } \\
\text { performance } \rightarrow \\
\text { perceived nega- } \\
\text { tive impact on } \\
\text { investment costs } \\
\text { and the efficiency } \\
\text { of design \& con- } \\
\text { struction works }\end{array}$ & $\begin{array}{l}\text { Not identified at } \\
\text { network level } \\
\text { Maintaining } \\
\text { margin of the de- } \\
\text { sign \& construc- } \\
\text { tion works } \\
\text { Creating value } \\
\text { for the client (de- } \\
\text { veloper) through } \\
\text { solutions that } \\
\text { lower investment } \\
\text { costs }\end{array}$ & $\begin{array}{l}\text { * Project develop- } \\
\text { ment, design \& } \\
\text { construction, op- } \\
\text { erations } \\
\text { Maintaining } \\
\text { margin of the FM } \\
\text { services through } \\
\text { technical solutions } \\
\text { that e.g. improve } \\
\text { the service efficien- } \\
\text { cy and life cycle of } \\
\text { technical systems }\end{array}$ & $\begin{array}{l}\text { Not identified } \\
\text { at network } \\
\text { level } \\
\text { Maintaining } \\
\text { the margin of } \\
\text { the service } \\
\text { Creating value } \\
\text { for the client } \\
\text { through im- } \\
\text { proved service } \\
\text { quality }\end{array}$ \\
\hline Lock-in & $\begin{array}{l}{ }^{*} \text { Operations } \\
* * \text { Ability to ap- } \\
\text { propriate value } \\
\text { throughout the } \\
\text { service provision } \\
\text { phase } \\
\text { Utilisation of in- } \\
\text { novations in oper- } \\
\text { ations to maintain } \\
\text { the margin of the } \\
\text { life-cycle manage- } \\
\text { ment operations }\end{array}$ & $\begin{array}{l}\text { Not identified } \\
\text { Asset appreciation } \\
\text { through reduced } \\
\text { market risk }\end{array}$ & $\begin{array}{l}\text { Not identified at } \\
\text { network level }\end{array}$ & $\begin{array}{l}\text { Not identified at } \\
\text { network level }\end{array}$ & $\begin{array}{l}\text { * Operations } \\
\text { Maintaining } \\
\text { margin of the FM } \\
\text { services through } \\
\text { increased learn- } \\
\text { ing of the client's } \\
\text { needs } \rightarrow \\
\text { incremental in- } \\
\text { novations in opera- } \\
\text { tions } \\
\text { Export of inno- } \\
\text { vations to other } \\
\text { locations \& clients } \\
\text { (econ. of scope) }\end{array}$ & $\begin{array}{l}\text { Not identified } \\
\text { at network } \\
\text { level } \\
\text { Creating busi- } \\
\text { ness opportuni- } \\
\text { ties through } \\
\text { the continua- } \\
\text { tion of services } \\
\text { and winning } \\
\text { new contracts } \\
\text { from the cli- } \\
\text { ents }\end{array}$ \\
\hline
\end{tabular}




\begin{tabular}{|c|c|c|c|c|c|c|}
\hline & \multicolumn{2}{|l|}{ Developer } & \multicolumn{2}{|l|}{ Contractor } & \multicolumn{2}{|l|}{ FM service provider } \\
\hline & Integra & Standard & Integra & Standard & Integra & Standard \\
\hline \multicolumn{7}{|c|}{ (Continued) } \\
\hline Risk & $\begin{array}{l}\text { * Project develop- } \\
\text { ment, design \& } \\
\text { construction, op- } \\
\text { erations } \\
\text { Absorption of } \\
\text { performance and } \\
\text { technical risks, } \\
\text { providing life-cy- } \\
\text { cle performance to } \\
\text { the client against } \\
\text { functionality cri- } \\
\text { teria. } \\
\text { Efficient use of } \\
\text { life-cycle funds } \\
\text { to ensure the } \\
\text { balance between } \\
\text { maintenance costs } \\
\text { and technical re- } \\
\text { placements } \\
\text { Development of } \\
\text { analysis tools and } \\
\text { capabilities to } \\
\text { demonstrate and } \\
\text { price the techni- } \\
\text { cal, operational } \\
\text { and life-cycle risk }\end{array}$ & $\begin{array}{l}\text { * Project develop- } \\
\text { ment } \\
\text { Asset appreciation } \\
\text { through reduced } \\
\text { market risk } \\
\text { To comply with the } \\
\text { risk preferences of } \\
\text { investors, i.e. cre- } \\
\text { ating value for the } \\
\text { client (investors) }\end{array}$ & $\begin{array}{l}\text { * Project develop- } \\
\text { ment, design \& } \\
\text { construction } \\
\text { Design \& con- } \\
\text { struction: Con- } \\
\text { struction of the } \\
\text { buildings against } \\
\text { guaranteed price } \\
\text { and schedule-ab- } \\
\text { sorption of risks } \\
\text { related to con- } \\
\text { struction schedule } \\
\text { and costs } \\
\text { Emphasis on risk } \\
\text { management and } \\
\text { operational ef- } \\
\text { ficiency after con- } \\
\text { tractual close }\end{array}$ & $\begin{array}{l}\text { * Design \& con- } \\
\text { struction } \\
\text { Creating value for } \\
\text { the client (devel- } \\
\text { oper) through low- } \\
\text { ering developer's } \\
\text { risk position } \\
\text { Maintaining } \\
\text { margin of the } \\
\text { design \& con- } \\
\text { struction works } \rightarrow \\
\text { efficiency }\end{array}$ & $\begin{array}{l}\text { * Project develop- } \\
\text { ment, design \& } \\
\text { construction, op- } \\
\text { erations } \\
\text { Providing guar- } \\
\text { antees for the } \\
\text { performance level } \\
\text { of services -> focus } \\
\text { on efficiency } \\
\text { Operations: Pro- } \\
\text { viding mainte- } \\
\text { nance services to } \\
\text { the client against } \\
\text { functionality crite- } \\
\text { ria. Absorption of } \\
\text { performance and } \\
\text { technical risks. }\end{array}$ & Not identified \\
\hline
\end{tabular}

* The project delivery phases when the identified value driver is dominant. ** The value appropriation mechanism of the identified value drivers.

\section{DISCUSSION AND CONCLUSIONS}

Successful business model renewal requires the companies to understand the changes that the new business models causes with respect to the activities, value drivers and value appropriation logic of the firms. This understanding can not be achieved focusing on the transactions or process phases only. Instead, there is a need to look inside the "black box" of firm activities at intra- and inter-firm levels (Leiringer, Bröchner 2010). Our study adopts this activity-based perspective when analyzing the differences in the business models of firms participating in an integrated solutions delivery network, and in conventional project delivery networks.

In our study we demonstrate how case firms participating in an integrated project and service delivery have to re-design their value drivers, compared to their business models applied in more disintegrated project deliveries. However, at the same time, they manage the complexity by adhering to their existing activity content and governance models.

Using the Zott and Amit (2010) framework we could show that the design elements, i.e. activity system content, structure and governance, of the participating companies' business models in both integrated and standard project delivery remained surprisingly similar. However, the design theme dimension of the business model in the Integra case faced major changes compared to Standard case. The results show that in Integra, the dominant design themes vary across the building life-cycle stages, but are aligned across the consortium participants. This creates a mechanism where the utilisation of a design theme enhances the effect of other design themes, and creates a strong fit between the business models of project participants (Porter, Siggelkow 2001). The high risk position of the consortium companies and their approach to sharing the risk further enforced this. Indeed, our results suggest that that a new fifth design theme, "risk", should be included when a construction project business models are evaluated.

Our results appear to contradict previous studies to some extent and thus bring new perspectives to the earlier research that posits that that the existing structures of construction companies form a barrier toward the transition to more integrated and service-led project delivery modes (Leiringer, 
Schweber 2010). Our results indicate that that embracing existing structures can actually be an effective way to manage complexity. This finding is in line with the view of organisational theories (Simon 1969), and the empirical studies of e.g. Windahl and Lakemond (2006) which conclude that the development of new products and services, by embracing existing organisational subsystems is potentially much more efficient than re-creating the offering by putting together a large number of individual factors.

An additional interesting finding is that the joint alignment of design themes had an effect on the perceived relationship of the network companies. In the Integra case, the network integration was facilitated and the threat of opportunism reduced, by allowing the partners explicitly maximize their own private benefits. This result is in line with management literature on alliances and partnering (Das, Teng 2001) and also with more REC sector specific literature (e.g. Dainty et al. 2001). In the Standard case, despite the fact that the actors perceived their project as being economically successful, the participants felt that the building delivery was characterised by mistrust and challenges in co-operation, fed by the experience of "being treated fairly".

It can be stated, that adjusting one value driver across the project e.g. though incentives, such as innovations, risk allocation or the holding period of the service contract is not sufficient to create integration in the project networks. It is the interplay of all value drivers and their mutual complementarity that is critical in creating a mutually aligned project network, that is able to efficiently create and appropriate value. Therefore recommendations on optimal approaches for integration cannot be given by just examining a single aspect of a business model.

The paper does not aim to evaluate whether either of the analysed business models are superior in terms of financial or social performance or the quality of the outputs. Integration of construction sector products and services is a wide spread phenomenon and is increasingly requested not only by the public sector, but also by the private sector clients. Therefore researching its implications on the real estate construction and service industry are warranted in their own right.

\section{Limitations}

There are a number of limitations in the applied approach that need to be recognised. The case studies were focusing on organisations in a mar- kets, where large contractors also acting as project developers is a standard market practice. In addition, the study was conducted during the construction and hand-over phases of the case buildings. As such, it provides visibility to only a narrow perspective of the project, where there is only limited experience on the operational phase of the project. Thus, the observed expectations of the organisations concerning the service provision phase of the can only fully be confirmed when the operational services provision has stabilised and anticipated divestments have been completed. Therefore, the study should be repeated after some time has passed after hand over to verify the organisational implications of service provision and to the FM organisation.

\section{Implications}

The study makes four contributions to the evolving research on real estate and construction sector business models: First, this is the first study of which we are aware that explores the real estate and construction sector business models from the perspective of firms participating to the project delivery network. Secondly, it extends the unit of analysis outside the traditional scope of a construction project to the role of value creation through asset appropriation, thus incorporating the aspects of project research to the streams of property management and investment. Thirdly, this study conceptualises business models through activities, which enables the analysis of the entire value creating system of a focal firm, without being bound to the organizational or transactional boundaries, as set forth by contractual theories (Sheehan, Foss 2007; Zott, Amit 2008). Fourth, it adds a component of risk as a design theme to Amit and Zott (2010) activity based business model analysis.

This is the first study of we know that focuses on the REC sector business models from interfirm perspective. It conceptualization of business models through activities enables a richer analysis of business model drivers at intra and inter-firm levels than reducing a business model to a set of transactions only. For practitioners, the findings suggest that firms wishing to develop more integrated product \& service deliveries should primarily utilize their existing activity and resource base and focus on aligning their value appropriation logic as the main driver for inter-firm alignment of business models. One critical factor in this is the mutually shared understanding of the customer(s) and their relative impact on activity choices. 
So far, research on the fashionable field of integrated solutions and alliances has primarily focused on developing practices from the perspective of a customer - producer relationship. This study gives valuable insights related the importance of the internal logic of the service providers in achieving successful project coalition. For practitioners, the findings suggest that firms wishing to develop more integrated product \& service deliveries should primarily create a commercial structure that enables all parties to fulfil their financial objectives and utilise their existing resource base. One critical factor in this is the mutually shared understanding of the customer(s) and their relative impact on activity choices. This, in turn, requires that companies are able to transparently communicate their commercial boundary conditions as part of network formation process, both from the project-firm perspective and project lifecycle perspectives.

\section{REFERENCES}

Amit, R.; Zott, C. 2001. Value creation in e-business, Strategic Management Journal 22(6-7): 493-520. https://doi.org/10.1002/smj.187

Ankrah, N. A.; Proverbs, D.; Debrah, Y. 2009. Factors influencing the culture of a construction project organisation: an empirical investigation, Engineering, Construction and Architectural Management 16(1): 26-47. https://doi.org/10.1108/09699980910927877

Anvuur, A. M.; Kumaraswamy, M. M. 2007. Conceptual model of partnering and alliancing, Journal of Construction Engineering and Management 133(3): 225-234. https://doi.org/10.1061/(ASCE)07339364(2007)133:3(225)

Baiden, B. K.; Price, A. D. F.; Dainty, A. R. J. 2006. The extent of team integration within construction projects, International Journal of Project Management 24(1): 13-23. https://doi.org/10.1016/j.ijproman.2005.05.001

Barlow, J. 2000. Innovation and learning in complex offshore construction projects, Research Policy 29(7-8): 973-989. https://doi.org/10.1016/S00487333(00)00115-3

Blayse, A. M.; Manley, K. 2004. Key influences on construction innovation, Construction Innovation 4: 143-154. https://doi.org/10.1108/14714170410815060

Brady, T.; Davies, A.; Gann, D. 2005a. Can integrated solutions business models work in construction?, Building Research \& Information 33(6): 571-579. https://doi.org/10.1080/09613210500285064

Brady, T.; Davies, A.; Gann, D. 2005b. Creating value by delivering integrated solutions, International Journal of Project Management 23(5): 360-365. https://doi.org/10.1016/j.ijproman.2005.01.001

Bresnen, M.; Marshall, N. 2000a. Motivation, commitment and the use of incentives in partnerships and alliances, Construction Management and Economics 18(5): 587-598.

https://doi.org/10.1080/014461900407392

Bresnen, M.; Marshall, N. 2000b. Partnering in construction: a critical review of issues, problems and dilemmas, Construction Management and Economics 18(2): 229-237. https://doi.org/10.1080/014461900370852

Brewer, G.; Gajendran, T.; Jefferies, M.; McGeorge, D.; Rowlinson, S.; Dainty, A. 2013. Value through innovation in long-term service delivery: facility management in an Australian PPP, Built Environment Project and Asset Management 3(1): 74-88. https://doi.org/10.1108/BEPAM-03-2012-0008

Briscoe, G. H.; Dainty, A. R. J.; Millett, S. J.; Neale, R. H. 2004. Client-led strategies for construction supply chain improvement, Construction Management and Economics 22(2): 193-201. https://doi.org/10.1080/0144619042000201394

Bygballe, L. E.; Ingemansson, M. 2014. The logic of innovation in construction, Industrial Marketing Management 43(3): 512-524. https://doi.org/10.1016/j. indmarman.2013.12.019

Chesbrough, H.; Rosenbloom, R. S. 2002. The role of the business model in capturing value from innovation: evidence from Xerox corporation's technology spin-off companies, Industrial and Corporate Change 11(3): 529-555. https://doi.org/10.1093/icc/11.3.529

Consoli, G. G. S. 2006. Conflict and managing consortia in private prison projects in Australia - private prison operator responses, International Journal of Project Management 24(1): 75-82.

https://doi.org/10.1016/j.ijproman.2005.06.007

Dainty, A. R. J.; Millett, S. J.; Briscoe, G. H. 2001. New perspectives on construction supply chain integration, Supply Chain Management: An International Journal 6(4): 163-173. https://doi.org/10.1108/13598540110402700

Das, T. K.; Teng, B. S. 2001. Trust, control, and risk in strategic alliances: an integrated framework, Organization Studies 22(2): 251-283. https://doi.org/10.1177/0170840601222004

Davies, A. 2004. Moving base into high-value integrated solutions: a value stream approach, Industrial and Corporate Change 13(5): 727-756. https://doi.org/10.1093/icc/dth029

Dubois, A.; Gadde, L. E. 2002a. The construction industry as a loosely coupled system: implications for productivity and innovation, Construction Management and Economics 20(7): 621-631. https://doi.org/10.1080/01446190210163543

Dubois, A.; Gadde, L. E. 2002b. Systematic combining: an abductive approach to case research, Journal of Business Research 55(7): 553-560. https://doi.org/10.1016/S0148-2963(00)00195-8

Eccles, R. G. 1981. The quasifirm in the construction industry, Journal of Economic Behavior \& Organization 2(4): 335-357. https://doi.org/10.1016/01672681(81)90013-5

Eisenhardt, K. M. 1989. Building theories from case study research, Academy of Management Review 14(4): 532-550. https://doi.org/10.5465/AMR.1989.4308385 
Gann, D. M.; Salter, A. J. 2000. Innovation in projectbased, service-enhanced firms: the construction of complex products and systems, Research Policy 29(7-8): 955-972. https://doi.org/10.1016/S00487333(00)00114-1

Goddard, G. J.; Marcum, B. 2012. Real estate investment: a value based approach. Springer Texts in Business and Economics. Springer-Verlag Berlin Heidelberg.

https://doi.org/10.1007/978-3-642-23527-6

Hobday, M. 1998. Product complexity, innovation and industrial organisation, Research Policy 26(6): 689710. https://doi.org/10.1016/S0048-7333(97)00044-9

Jensen, P. A. 2009. Design integration of facilities management: a challenge of knowledge transfer, Architectural Engineering and Design Management 5(3): 124-135. https://doi.org/10.3763/aedm.2009.0101

Leiringer, R.; Bröchner, J. 2010. Editorial: service-led construction projects, Construction Management and Economics 28(11): 1123-1129. https://doi.org/10.1080 /01446193.2010.532591

Leiringer, R.; Schweber, L. 2010. Managing multiple markets: big firms and PFI, Building Research \& Information 38(2): 131-143. https://doi. org/10.1080/09613210903027147

Lindahl, G.; Ryd, N. 2007. Clients' goals and the construction project management process, Facilities 25(3/4): 147-156. https://doi.org/10.1108/02632770710729737

Liu, A.; Fellows, R.; Fang, Z. 2003. The power paradigm of project leadership, Construction Management and Economics 21(8): 819-829. https://doi.org/10.1080/0144619032000056199

Majamaa, W.; Junnila, S.; Doloi, H.; Niemistö, E. 2008. End-user oriented public-private partnerships in real estate industry, International Journal of Strategic Property Management 12(1): 1-17. https://doi.org/10.3846/1648-715X.2008.12.1-17

Mason, K.; Spring, M. 2011. The sites and practices of business models, Industrial Marketing Management 40(6): 1032-1041. https://doi.org/10.1016/j.indmarman.2011.06.032

Meredith, J. 1998. Building operations management theory through case and field research, Journal of Operations Management 16(4): 441-454. https://doi.org/10.1016/S0272-6963(98)00023-0

Nam, C. H.; Tatum, C. B. 1988. Major characteristics of constructed products and resulting limitations of construction technology, Construction Management and Economics 6(2): 133-147.

https://doi.org/10.1080/01446198800000012

Nam, C. H.; Tatum, C. B. 1992. Noncontractual methods of integration, Journal of Construction Engineering and Management 118(2): 385-398. https://doi. org/10.1061/(ASCE)0733-9364(1992)118:2(385)

Osterwalder, A.; Pigneur, Y.; Tucci, C. L. 2005. Clarifying business models: origins, present, and future of the concept, Communications of the Association for Information Systems 16(1). Available at: http://aisel. aisnet.org/cais/vol16/iss1/1

Pettigrew, A. M. 1990. Longitudinal field research on change: theory and practice, Organization Science 1(3): 267-292. https://doi.org/10.1287/orsc.1.3.267
Porter, M. E. 1985. Competitive advantage. New York: The Free Press.

Porter, M. E. 1991. Towards a dynamic theory of strategy, Strategic Management Journal 12(S2): 95-117. https://doi.org/10.1002/smj.4250121008

Porter, M. E.; Siggelkow, N. 2001. Contextuality within activity systems, Academy of Management Perspectives 22(2): 34-56. https://doi.org/10.5465/ AMP.2008.32739758

Rutten, M. E. J.; Dorée, A. G.; Halman, J. I. M. 2009. Innovation and interorganizational cooperation: a synthesis of literature, Construction Innovation 9(3): 285-297. https://doi.org/10.1108/14714170910973501

Sheehan, N. T.; Foss, N. J. 2007. Enhancing the prescriptiveness of the resource-based view through Porterian activity analysis, Management Decision 45(3): 450-461. https://doi.org/10.1108/00251740710745070

Simon, H. A. 1969. The sciences of the artificial. The MIT Press.

Stabell, C. B.; Fjelstad, O. 1998. Configuring value for competitive advantage: on chains, shops, and networks, Strategic Management Journal 19(5): 413-437. https://doi.org/10.1002/(SICI)10970266(199805)19:5<413::AID-SMJ946>3.0.CO;2-C

Teece, D. J. 2010. Business models, business strategy and innovation, Long Range Planning 43(2-3): 172194. https://doi.org/10.1016/j.lrp.2009.07.003

Thomas, L. D. W.; Autio, E.; Gann, D. M. 2014. Architectural leverage: putting platforms in context, Academy of Management Perspectives 28(2): 198-219. https://doi.org/10.5465/amp.2011.0105

Wikström, K.; Artto, K.; Kujala, J.; Söderlund, J. 2010. Business models in project business, International Journal of Project Management 28(8): 832-841. https://doi.org/10.1016/j.ijproman.2010.07.001

Winch, G. 1998. Zephyrs of creative destruction: understanding the management of innovation in construction, Building Research \& Information 26(5): 268-279. https://doi.org/10.1080/096132198369751

Winch, G. M. 2001. Governing the project process: a conceptual framework, Construction Management and Economics 19(8): 799-808.

https://doi.org/10.1080/01446190110074264

Windahl, C.; Lakemond, N. 2006. Developing integrated solutions: the importance of relationships within the network, Industrial Marketing Management 35(7): 806-818. https://doi.org/10.1016/j.indmarman.2006.05.010

Yin, R. K. 2003. Case study research: design and methods. Applied Social Research Methods Series, Volume 5. $3^{\text {rd }}$ ed. Thousand Oaks: SAGE Publications, Inc.

Zott, C.; Amit, R. 2008. The fit between product market strategy and business model: implications for firm performance, Strategic Management Journal 29(1): 1-26. https://doi.org/10.1002/smj.642

Zott, C.; Amit, R. 2010. Business model design: an activity system perspective, Long Range Planning 43(23): 216-226. https://doi.org/10.1016/j.lrp.2009.07.004

Zott, C.; Amit, R.; Massa, L. 2011. The business model: recent developments and future research, Journal of Management 37(4): 1019-1042.

https://doi.org/10.1177/0149206311406265 


\section{APPENDIX 1. Data sources, collected data and its use in the analysis}

Data sources, type of data and its use in the analysis

\begin{tabular}{|c|c|c|}
\hline Primary & $\begin{array}{l}\text { Main contract of the project (Client-Developer) } \\
\text { - Service levels (definitions of the service output) } \\
\text { - Pricing basis and mechanisms } \\
\text { - Risk division }\end{array}$ & $\begin{array}{l}\text { Partnering agreement and main contract of the } \\
\text { project (Developer-Contractor) } \\
\text { - Service definitions, timeline } \\
\text { - Pricing basis and mechanisms } \\
\text { - Risk division }\end{array}$ \\
\hline Primary & $\begin{array}{l}6 \text { semi-structured interviews } \\
\text { - Business strategy and management model } \\
\text { - Business model drivers and activities } \\
\text { - Relationship within the network and the client } \\
\text { - Resources and organizational structures }\end{array}$ & $\begin{array}{l}9 \text { semi-structured interviews } \\
\text { - Business strategy and management model } \\
\text { - Business model drivers and activities } \\
\text { - Relationship within the network and the } \\
\text { client } \\
\text { - Resources and organizational structures }\end{array}$ \\
\hline Primary & $\begin{array}{l}7 \text { month participant observatory } \\
\text { - Identification of co-operation \& management } \\
\text { culture within the network } \\
\text { - Informal authority structures } \\
\text { - Conflict management strategies } \\
\text { - Factors affecting trust }\end{array}$ & $\begin{array}{l}12 \text { month participant observatory } \\
\text { - Identification of co-operation \& manage- } \\
\text { ment culture within the network } \\
\text { - Informal authority structures } \\
\text { - Conflict management strategies } \\
\text { - Factors affecting trust }\end{array}$ \\
\hline Secondary & $\begin{array}{l}\text { Site visits } \\
\text { - Triangulate facts and observations, enhance } \\
\text { validity of insights }\end{array}$ & $\begin{array}{l}\text { Site visits } \\
\text { - Triangulate facts and observations, en- } \\
\text { hance validity of insights }\end{array}$ \\
\hline Secondary & $\begin{array}{l}\text { Project websites, presentations and other project } \\
\text { material } \\
\text { - Triangulate facts and observations, enhance } \\
\text { validity of insights }\end{array}$ & $\begin{array}{l}\text { Project websites, presentations and other project } \\
\text { material } \\
\text { - Triangulate facts and observations, en- } \\
\text { hance validity of insights }\end{array}$ \\
\hline
\end{tabular}

